\title{
RADIOCARBON DATING OF UNDERWATER ARCHAEOLOGICAL OBJECTS FROM THE NEVADO DE TOLUCA, MEXICO
}

\author{
M A Martínez-Carrillo ${ }^{*} \cdot \mathrm{C} \mathrm{Solís}^{2} \cdot \mathrm{I}_{\text {Hernández Bautista }}{ }^{3} \cdot \mathrm{R}$ Junco Sánchez ${ }^{3} \bullet$ \\ $\mathrm{M}$ Rodríguez-Ceja ${ }^{2} \cdot \mathrm{M} \mathrm{E} \mathrm{Ortiz}{ }^{2} \cdot \mathrm{E}_{\text {Chávez-Lomelí }}^{2}$ \\ ${ }^{1}$ Facultad de Ciencias, Universidad Nacional Autónoma de México (UNAM), Ave. Universidad 3000, Ciudad \\ Universitaria, 04510, Mexico City, Mexico. \\ ${ }^{2}$ Instituto de Física, Universidad Nacional Autónoma de México (UNAM), Ave. Universidad 3000, 04510, Mexico \\ City, México. \\ ${ }^{3}$ Subdirección de Arqueología Subacuática, Instituto Nacional de Antropología e Historia, Moneda 16, 06700, \\ Mexico City, Mexico.
}

\begin{abstract}
The Nevado de Toluca is a stratovolcano located in the southwest of the Toluca Valley in central Mexico. At a height of around $4200 \mathrm{~m}$ there are two crater lakes: El Sol and La Luna. Since Precolumbian times, people in the surrounding valleys carried out rituals and deposited offerings into the lakes. After the Spanish conquest, these rituals were kept alive clandestinely. Currently, reminiscent of Mesoamerican rituals subsist. Due to the long duration of the ritual at the Nevado de Toluca, it is important to date the materials recovered in the underwater and terrestrial archaeological explorations. This article proposes a chronology of Prehispanic ritual activities performed in the Nevado de Toluca based on the characterization and radiocarbon $\left({ }^{14} \mathrm{C}\right)$ dating performed to materials from the volcano's lakes.
\end{abstract}

KEYWORDS: AMS, Nevado de Toluca, radiocarbon dating.

\section{INTRODUCTION}

The Mexican landscape is characterized by a wide variety of landforms including hills, ridges, mountains, and volcanoes; this orography molded the worldview of Mesoamerican people, who considered these elements inhabited by spirits (Broda 2001). It is natural to assume that mountains and volcanoes were among the most sacred objects of veneration due to their physical link between heaven, earth, and the underworld as well as providers of food and water. Furthermore, mountains were perceived as supernatural beings associated with water and fertility and were the most important point of encounter between Tlaloc-the life cycle of water - and the landscape (Hernandez 2014). As a result, Mesoamerican people integrated these natural objects to their daily lives through the construction of "artificial mountains" or pyramids in their settlements, or sculptures carved in stone. Mountains and volcanoes with archaeological remains were probably the most immediate and ancient veneration objects. According to some historic accounts from the 16th and 17th centuries, societies that lived in the surrounding areas of the Nevado de Toluca in Prehispanic times performed rituals and offerings related to the worship of aquatic deities throughout the volcano. After the Spanish conquest, these ceremonies were hidden from Christian priests (Hernández 2014), leading to the fact that current cultural rituals remain, they can be linked somehow with the ancient Mesoamerican rites that focused on fertility of the fields, abundant harvests, the right amount of rain, and mild climate.

Over time, the man-volcano interaction has been recorded through materials deposited in the mountain. The El Sol and La Luna crater lakes in the Nevado de Toluca were chosen by Prehispanic societies to make offerings. Among the objects in these rituals were copal, a resin from the copal santo (Bursera bipinnata) tree used since Prehispanic times as a smelling smoke offering when burnt on censers; maguey thorns commonly used as a sharp object for selfsacrifice to injure different parts of the body and causing it to bleed, after which the blood is offered to the gods as described in historical accounts from the 16th and 17th centuries (Figure 1). And finally, wooden scepters (waved-shaped, carved wooden sticks) were made to

\footnotetext{
*Corresponding author. Email: mangel@ciencias.unam.mx.
} 


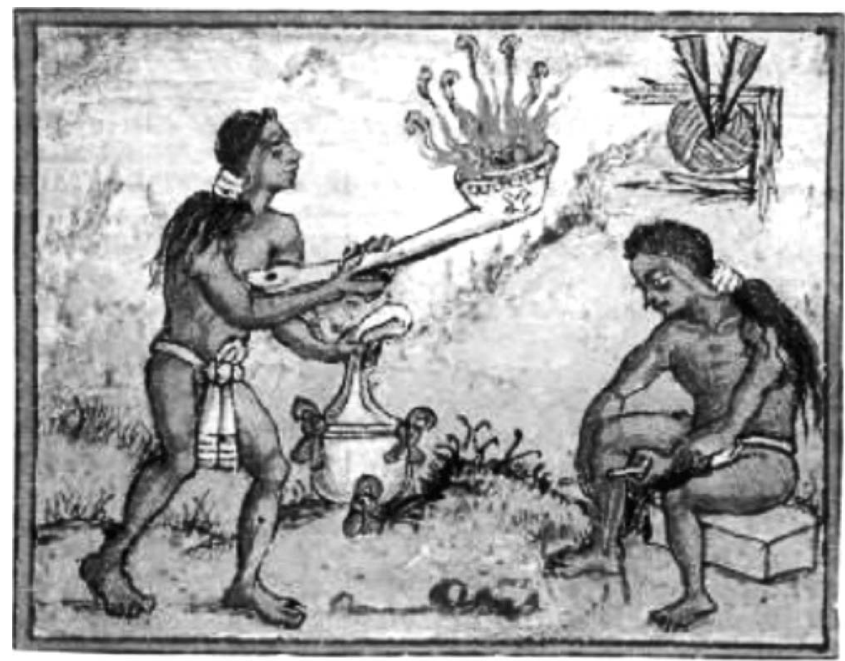

Figure 1 Representation of burning copal resin on a censer while a man perforates his calf. In the background, straw balls can be seen with deposited bleeding maguey thorns. Illustration taken from Historia de las Indias de la Nueva España e islas de tierra firme, Fray Diego Duran.
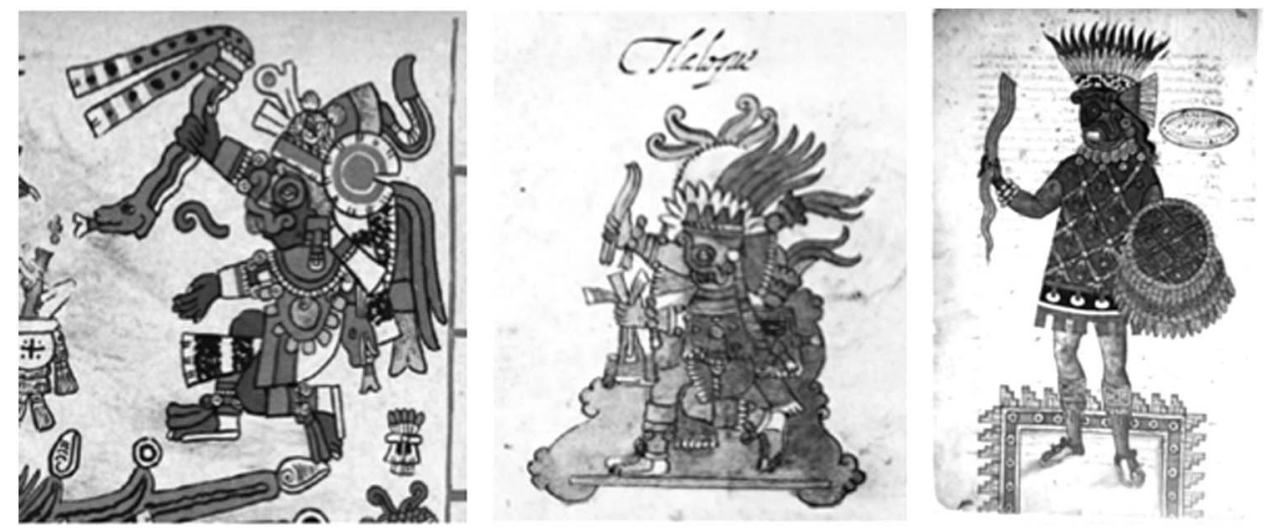

Figure 2 Three representations of Tlaloc holding an undulated scepter in his right hand. From left to right: fragments of Codex Borbónico, Codex Ríos, and Codex Ixtlilxochitl.

represent the lightning bolt/serpent scepter of Tlaloc (Junco and Vigliani 2012), a symbol of lightning and rain, one of its most characteristic attributes (Figure 2).

\section{SITE DESCRIPTION}

The Nevado de Toluca or Xinantecatl is a stratovolcano located in the southwest part of the Toluca Valley, in the State of Mexico at $19^{\circ} 06^{\prime} 31^{\prime \prime} \mathrm{N}$ and $99^{\circ} 45^{\prime} 29^{\prime \prime} \mathrm{W}$. It is the fourth-highest peak in Mexico with height of $4680 \mathrm{~m}$ asl (Yarza 2003). Inside the crater there are two perennial bodies of water known as El Sol and La Luna lakes both at $4200 \mathrm{~m}$ asl (Figure 3). By 2013, 27 archaeological sites in the Nevado de Toluca had been registered; four of them were part of the most important archaeological explorations in 2007, 2010, and 2012: La Luna (NT-07 Site) and 


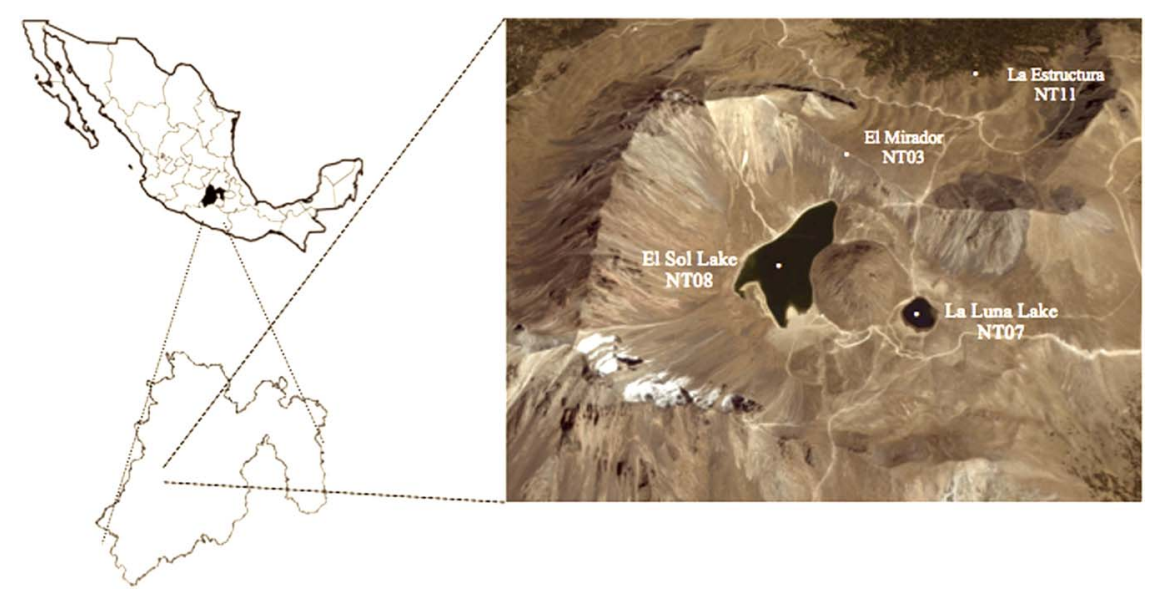

Figure 3 Map showing the Nevado de Toluca volcano in the State of Mexico. El Sol (NT08) and La Luna (NT07) crater lakes zoom in. Satellite photograph from Google Maps.

El Sol (NT-08 Site) lakes; El Mirador (NT-03 Site) and la Estructura (NT-11 Site), respectively. For this study, objects from La Luna (NT07) and E1 Sol (NT08) archaeological sites were used. These places have two archaeological contexts: land and underwater. In the northern bank of La Luna lake, ruins of stone and stucco were identified, possibly part of a ritual structure, as well as ceramic censers and remains of lithic and other pottery objects used in their rituals (Montero 2013). Additionally, remains of Prehispanic offerings had been found inside the lake, principally well-preserved objects made of organic materials like copal cones and spheres, wooden scepters, remains of basketry, as well as thorns and leaves of maguey. In the northern west bank over the land of El Sol lake, archeologists found a site with remains of pottery, charcoal, maguey thorns, fragments of wooden scepters, and numerous turquoise mosaic pieces. Most importantly, they were found beneath the water (Montero et al. 2009). It is worth mentioning that the site with archaeological remains found out of the water is flooded when the level of the lake increases in the rainy season. (Hernandez 2014).

Although the lakes were known to have had a lot of archaeological objects under their waters, they were looted by sport divers in the last half of the 20th century. This looting, along with natural alterations of archaeological lake contexts, have compromised the archaeological record and made it difficult to establish a clear stratigraphy. Nevertheless, the exceptional preservation conditions that the lakes' cold water and intense UV radiation (Alcocer 2009) provides to the organic archaeological material has made it possible to date the ritual activities in the volcano.

\section{MATERIALS AND METHODS}

\section{Sampling}

From the organic materials' offerings recovered in the lakes of El Sol (NT08) and La Luna (NT07), 21 were selected as the most representative samples from the lake bottoms: 14 Tlaloc's scepters, 4 maguey thorns, 3 copal resin pieces, and 1 rubber disc. Because of their composition and characteristics, these materials are ideal for radiocarbon $\left({ }^{14} \mathrm{C}\right)$ dating. Except for two maguey thorns (LEMA 530 and LEMA 531) from El Sol Lake and a rubber disc (LEMA 561) from La Luna Lake, all the objects had already been consolidated for preservation, possibly with polyethylene glycol (PEG)/ethylene glycol. 


\section{Sample Preparation}

The larger group is comprised of consolidated samples: 14 wooden objects (Figure 4), 13 extracted from La Luna lake (LEMA 532-540, LEMA 540, and LEMA 544-546), 1 (LEMA 547) from El Sol lake (LEMA 547), and 2 maguey thorns (LEMA 528 and LEMA 529) from El Sol lake. After mechanical cleaning, the consolidants were removed using an automated continuous extraction Sohxlet system (Büchi Labortechnik; E-812) for $2 \mathrm{hr}$ with n-hexane, 2-propanol and ethanol. At the end the samples were washed with hot ultrapure water. The second group of samples, 2 maguey thorns, 2 copal pieces, and 1 piece of rubber were cleaned and washed followed by ABA treatment method: The samples were treated with $0.5 \mathrm{M}[\mathrm{HCl}]_{\mathrm{aq}}$ at $60^{\circ} \mathrm{C}$ for $10 \mathrm{hr}$ and then rinsed with deionized water to neutral $\mathrm{pH}$. They were then treated with $0.1 \mathrm{M}[\mathrm{NaOH}]_{\mathrm{aq}}$ at $60^{\circ} \mathrm{C}$ for $10 \mathrm{hr}$ and rinsed with deionized water to neutral $\mathrm{pH}$. Finally, the samples were treated with $0.5 \mathrm{M}[\mathrm{HCl}]_{\mathrm{aq}}$ at $60^{\circ} \mathrm{C}$ for $10 \mathrm{hr}$, rinsed with deionized water, and dried in an oven at $50^{\circ} \mathrm{C}$ for $12 \mathrm{hr}$. Once clean, all wooden pieces and maguey thorns were subjected to cellulose extraction process by base-acid-base-acid-bleaching method (Němec et al. 2010). The samples were treated with $4 \%[\mathrm{NaOH}]_{\mathrm{aq}}$ at $75^{\circ} \mathrm{C}$ for $10 \mathrm{hr}$ and rinsed with deionized water until neutral $\mathrm{pH}$. Then they were treated with $4 \%[\mathrm{HCl}]_{\mathrm{aq}}$ at $75^{\circ} \mathrm{C}$ for $1 \mathrm{hr}$ and rinsed with deionized water to neutral $\mathrm{pH}$. After that, they were treated with $4 \%[\mathrm{NaOH}]_{\mathrm{aq}}$ at $75^{\circ} \mathrm{C}$ for $1.5 \mathrm{hr}$ and rinsed with deionized water to neutral $\mathrm{pH}$. And finally they were treated with $5 \%$ $\left[\mathrm{NaClO}_{2}\right]_{\mathrm{aq}}$ to which was added $5 \%[\mathrm{HCl}]_{\mathrm{aq}}$ to $\mathrm{pH}=2$, kept at $75^{\circ} \mathrm{C}$ for $2 \mathrm{hr}$. They were then rinsed to neutral $\mathrm{pH}$, decanted, and dried by lyophilization.

For AMS- ${ }^{14} \mathrm{C}$ analyses, the cellulose, copal, and rubber samples obtained were transformed to graphite using a commercial Automatic Graphitization Equipment (AGEIII; IonPlus) (Wacker et al. 2010). In this apparatus, an elemental analyzer (EA; Elementar, Vario Micro Cube) is coupled to a compact and fully automated graphitizer. The sample is weighted in a tin crucible and introduced into the EA, where it is combusted at $950^{\circ} \mathrm{C}$. The $\mathrm{CO}_{2}$ produced is separated

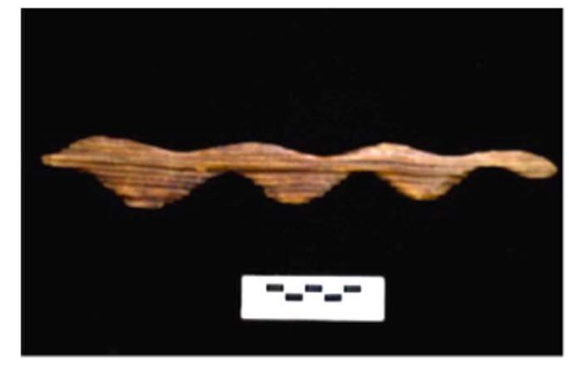

1

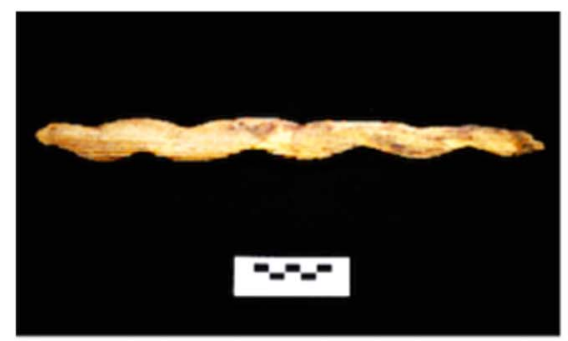

3

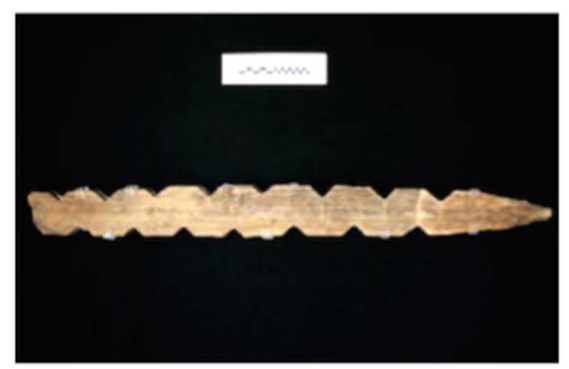

2

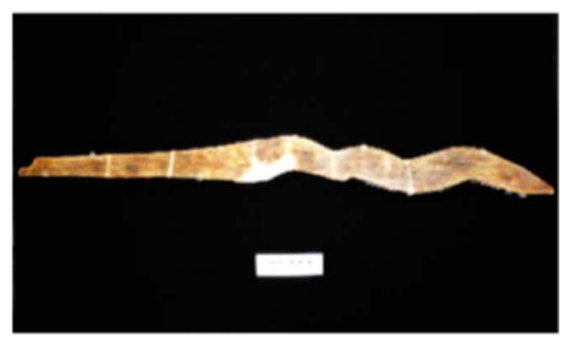

4

Figure 4 Four undulated wooden scepters with different sizes and shapes recovered from Lake La Luna: (1) LEMA 537; (2) LEMA 547; (3) LEMA 542; and (4) LEMA 545. 
from $\mathrm{N}_{2}, \mathrm{SO}_{2}$, and $\mathrm{H}_{2} \mathrm{O}$ and transferred to the graphitizer by helium as carrier gas, where it is absorbed in a zeolite trap. $\mathrm{CO}_{2}$ is then transferred from the zeolite to each one of seven reactors, where the graphite is formed at $580^{\circ} \mathrm{C}$ in the presence of $\mathrm{H}_{2}$ and $\mathrm{Fe}$ powder catalyst. Routine preparation of $1 \mathrm{mg}$ carbon of some International Atomic Energy Agency (IAEA) reference materials as from National Institute of Standards and Technology (NIST) NIST 4990C oxalic acid (OXAII), were performed for standard normalization and correction for isotope fractionation. ${ }^{14} \mathrm{C}$-free blanks (phthalic acid blank) were used for quantify the backgrounds of combustion, graphitization a spectrometer. Measuring standard reference materials supplied by the IAEA assessed the accuracy of the ${ }^{14} \mathrm{C}$ analyses. The performance of the ${ }^{14} \mathrm{C}$ preparation laboratories was tested through the analysis of VIRI-2 (Fifth International Radiocarbon Intercomparison), sample F (Scott 2010). Our results for VIRI F (horse bone) dating were $2520 \pm 50 \mathrm{BP}$ (consensus values $2513 \pm 40 \mathrm{BP}$ ).

Corresponding ${ }^{14} \mathrm{C}$ dates were calculated using computer codes developed at LEMA (Solís et. al. 2014). Calendar ages were obtained with OxCal program v4.2.4 (https://c14.arch.ox.ac.uk/ oxcal/OxCal.html; Bronk Ramsey and Lee 2013), using the InCal13 calibration curve (Reimer et al. 2013). The OxCal program is basic for calculating the calendar ages and to be compared with those predicted for any site (Bronk Ramsey 1995; Bronk Ramsey and Lee 2013).

\section{RESULTS AND DISCUSSION}

The main Mesoamerican civilizations (Teotihuacan, Zapoteca, and Maya) dominated the Mesoamerican Classic Period (200-900 AD); but their collapse towards the Epiclassic (700-900 AD) allowed the emergence of many centers of regional power, such as Matlazinca. The Matlazincas dominated an extensive territory, with some main trade routes to the south and the Pacific. In addition, it was a very fertile region with an important agricultural production. This made the Matlazinca region the object of conquest by the dominant warrior people in the Late Postclassic (1200-1521 AD), the Aztecs.

The earliest date for the 14 wooden objects goes back to the Epiclassical end (650-900 AD) and part of the Early Postclassical 900-1200 AD; while the rest of the pieces belong in between the Early Postclassical and part of the Late Postclassical (1200-1520 AD). Table 1 presents the results for all wooden samples. None of the dates for this objects goes beyond $1455 \mathrm{AD}$. This is an important result as it highlights the fact that all ritual activity dates to the period before the Aztec conquest of the Toluca Valley in 1476 AD. According to the archaeological record the control of the Toluca Valley by the Matlazinca culture happened from 1162 AD to 1474/76 AD (Piña Chan 1975). This permits us to put forward the idea that the highest frequency of ritual activity in the volcano happened during Matlalzinca times rather than in the following Aztec times, for whom one of two most important deities was Tlaloc, god of rain. Besides, the results demonstrate that organic archaeological objects from Nevado de Toluca are older than expected and remain in exceptional conditions. Nonetheless, we must take into account that other cultural groups also inhabited the region controlled by the Matlazinca when putting forward hypotheses about the ritual activity, and the meaning of these wooden objects in the region.

Table 2 shows dates for maguey thorns, associated with Mayhuel the pulque's female divinity, the alcoholic beverage, fertility and practice of ritual self-sacrifice. The thorns (LEMA 529 and LEMA 528) found in La Luna Lake (NT07) fall into the Late Postclassical period just like the wooden objects belong to a time previous to the Aztecs conquest of the Toluca Valley. On the other hand, thorns dates (LEMA 530 and LEMA 531) from El Sol Lake (NT08) are much later, 
Table 1 Results for all wooden samples.

\begin{tabular}{lllll}
\hline Lab code & ID/provenance/material & \multicolumn{1}{l}{$\begin{array}{l}{ }^{14} \mathrm{C} \text { age } \\
\mathrm{BP})\end{array}$} & Calibrated date $(2 \sigma)$ & Period \\
\hline LEMA 537.1.1 & 6/NT07 La Luna/wood & $1081 \pm 40$ & 884 AD-1024 AD & Epiclassical end-Early Postclassical \\
LEMA 538.1.1 & 7/NT07 La Luna/wood & $1024 \pm 30$ & 903 AD-1146 AD & Early Postclassical \\
LEMA 540.1.1 & 9/NT07 La Luna/wood & $974 \pm 40$ & 995 AD-1157 AD & Early Postclassical \\
LEMA 546.1.1 & 15/NT07 La Luna/wood & $882 \pm 40$ & 1035 AD-1241 AD & Early Postclassical-Beginning of the Late Postclassical \\
LEMA 533.1.1 & 2/NT07 La Luna/wood & $893 \pm 30$ & 1040 AD-1216 AD & Early Postclassical-Beginning of the Late Postclassical \\
LEMA 539.1.1 & 8/NT07 La Luna/wood & $861 \pm 40$ & 1044 AD-1260 AD & Early Postclassical-Beginning of the Late Postclassical \\
LEMA 536.1.1 & 5/NT07 La Luna/wood & $858 \pm 40$ & 1045 AD-1261 AD & Early Postclassical-Beginning of the Late Postclassical \\
LEMA 544.1.1 & 13/NT07 La Luna/wood & $837 \pm 40$ & 1050 AD-1271 AD & Early Postclassical-Beginning of the Late Postclassical \\
LEMA 547.1.1 & 16/NT08 El Sol/wood & $827 \pm 40$ & 1053 AD-1275 AD & Early Postclassical-Beginning of the Late Postclassical \\
LEMA 542.1.1 & 11/NT07 La Luna/wood & $775 \pm 40$ & 1184 AD-1287 AD & Early Postclassical-Beginning of the Late Postclassical \\
LEMA 535.1.1 & 4/NT07 La Luna/wood & $726 \pm 40$ & 1219 AD-1385 AD & Late Postclassical \\
LEMA 534.1.1 & 3/NT07 La Luna/wood & $699 \pm 40$ & 1250 AD-1393 AD & Late Postclassical \\
LEMA 532.1.1 & 1/NT07 La Luna/wood & $602 \pm 40$ & 1294 AD-1411 AD & Late Postclassical \\
LEMA 545.1.1 & 14/NT07 La Luna/wood & $571 \pm 40$ & 1299 AD-1428 AD & Late Postclassical \\
\hline
\end{tabular}

.


Table 2 Dates for maguey thorns.

\begin{tabular}{lllll}
\hline Lab code & $\begin{array}{l}\text { ID/provenance/ } \\
\text { material }\end{array}$ & ${ }^{14} \mathrm{C}$ age $(\mathrm{BP})$ & Calibrated date $(2 \sigma)$ & Period \\
\hline LEMA 529.1.1 & $\begin{array}{l}\text { 94/NT07 La Luna/ } \\
\text { maguey thorn }\end{array}$ & $640 \pm 40$ & $1281 \mathrm{AD}-1400 \mathrm{AD}$ & Late Postclassical \\
LEMA 528.1.1 & $\begin{array}{l}\text { 56/NT07 La Luna/ } \\
\text { maguey thorn }\end{array}$ & $498 \pm 30$ & $1398 \mathrm{AD}-1450 \mathrm{AD}$ & Late Postclassical \\
LEMA 530.1.1 & $\begin{array}{l}\text { 104/NT08 El Sol/ } \\
\text { maguey thorn } \\
\text { 105/NT08 El Sol/ } \\
\text { maguey thorn }\end{array}$ & $333 \pm 40$ & $1463 \mathrm{AD}-1645 \mathrm{AD}$ & $\begin{array}{l}\text { Late Postclassical- } \\
\text { Colonial period }\end{array}$ \\
LEMA 531.1.1 & $251 \pm 35$ & $1618 \mathrm{AD}-1682 \mathrm{AD}$ & Colonial period \\
\hline
\end{tabular}

Table 3 Results for copal and rubber samples from La Luna Lake.

\begin{tabular}{|c|c|c|c|c|}
\hline Lab code & Provenance/material & ${ }^{14} \mathrm{C}$ age (BP) & Calibrated date $(2 \sigma)$ & Period \\
\hline & & & & \\
\hline 1.1 & & & & \\
\hline LEMA 560.1 .1 & 61A NT07 La Luna/copal resin & $520 \pm 35$ & 1319 AD-1445 AD & Late Postclassical \\
\hline
\end{tabular}

belonging to the Colonial period. This means there is evidence of the ritual use of the lakes into the Colonial period. Table 3 shows results for two copal (LEMA 559 and LEMA 560) and one rubber (LEMA 561) samples from La Luna Lake (NT07). Copal is a plant resin of a tree with a short life cycle whose physical and chemical characteristics make it stable during a long period. Copal and rubber sample datings belong to the Late Postclassical previous to the Aztecs' arrival in the Toluca Valley.

The Prehispanic cult in the Nevado de Toluca ran from Epiclassical end to the 19th century. Nevertheless, it was more intense between the Early Postclassical and the Late Postclassical and almost disappeared around 1460 AD in coincidence with the Aztecs' first attacks that ended with the conquest of Matlazinca around 1479 AD. Rituals in the Nevado de Toluca in Later Postclassical also coincide with the Little Ice Age (1360-1910 AD), which brought the tendency of the region to have colder and drier weather. This climatological record has been established from the sediments of La Luna Lake, suggesting also the colder and drier weather (Cuna et al. 2014). Furthermore, also coinciding are some of the most intense or longest droughts, which were recorded for 1365-1384 AD, 1526 AD, and 1655-1670 AD (Sosa-Nájera et al. 2010). Thus the period that coincides with ritual activity in the volcano and weather patterns goes from $1360 \mathrm{AD}$ to $1500 \mathrm{AD}$, and from $1500 \mathrm{AD}$ to $1660 \mathrm{AD}$, approximately.

\section{CONCLUSIONS}

The AMS ${ }^{14} \mathrm{C}$ dating analyses conducted on various materials (wooden scelpters, copal, maguey thorns, and rubber) confirmed the use of the Nevado de Toluca volcano as a very active offering site.

Despite diverse context alterations, such as looting and weathering, most of the analyzed objects found at La Luna Lake were found under exceptional conservation conditions. ${ }^{14} \mathrm{C}$ dating has made it possible to obtain the first estimate of peak ritual activities at Nevado de 
Toluca. The analysis results suggest that the greatest period of ritual activity at the Nevado de Toluca was in the Late Postclassical period. This could have been related to a greater need for rain and to have better climatological conditions for growing crops.

Although the analysis of the short-live samples, such as maguey thorns and copal, allowed the establishment of a better chronology of the rituals at Nevado de Toluca, the wooden materials provided just rough estimates.

\section{ACKNOWLEDGMENTS}

The authors thank A. Huerta for maintenance and operation of the AMS system, and Sergio Martínez for laboratory assistance. This project was financed by Conacyt grants 232718 and 205317 and DGAPA-UNAM grants IG100313 and IG100216.

\section{REFERENCES}

Alcocer J. 2009. Limnología in Las aguas celestiales. Subdirección de Arqueología Subacuática. INAH.

Broda J, Iwaniszewski S, Montero García IA, editors. 2001. La Montaña en el Paisaje Ritual. CONACULTA, INAH, UNAM, UAP.

Bronk Ramsey C. 1995. Radiocarbon calibration and analysis of stratigraphy: the OxCal program. Radiocarbon 37(2):425-30.

Bronk Ramsey C, Lee S. 2013. Recent and planned developments of the program OxCal. Radiocarbon 55(2-3):720-30.

Cuna E, Zawusza E, Caballero M, Ruiz-Fernández AC, Lozano-García S, Alcocer J. 2014. Environmental impacts of Little Ice Age cooling in central México recorded in the sediments of a tropical alpine lake. Journal of Paleolimnology 51(1):1-14.

Hernández Bautista I. 2014. Ofrendas y paisajes rituales en el Nevado de Toluca [thesis]. Escuela Nacional de Antropología e Historia-INAH.

Junco R, Vigliani S. 2012. Paisaje de serpientes y montañas: estudio de los objetos de madera serpentiformes del Nevado de Toluca. In: Loera, Iwaniszewski, Cabrera, editors. Tierra de Volcanes y Montañas. INAH-ENAH, DEH.

Montero García IA. 2013. Excavaciones recientes en el flanco norte del Nevado de Toluca. In: Vigliani, Junco, editors. Bajo el Volcán, vida y ritualidad en torno al Nevado de Toluca. SEP CONACULTA INAH.

Montero García A, Junco Sánchez R. 2009. Informe del Proyecto Arqueología Subacuática en el Nevado de Toluca 2007. INAH-SAS. México.

Němec M, Wacker L, Hajdas I, Gäggeler H. 2010. Alternative methods for cellulose preparation for AMS measurement. Radiocarbon 52(2-3): 1358-70.
Piña Chan R. 1975. Teotenango. El antiguo lugar de la muralla. Memoria de las excavaciones arqueológicas. Volumes 1 and 2. Gobierno del Estado de México.

Reimer PJ, Bard E, Bayliss A, Beck JW, Blackwell PG, Bronk Ramsey C, Buck CE, Cheng H, Edwards RL, Friedrich M, Grootes PM, Guilderson TP, Haflidason H, Hajdas I, Hatté C, Heaton TJ, Hoffmann DL, Hogg AG, Hughen KA, Kaiser KF, Kromer B, Manning SW, Niu M, Reimer RW, Richards DA, Scott EM, Southon JR, Staff RA, Turney CSM, van der Plicht J. 2013. IntCall3 and Marine 13 radiocarbon age calibration curves 0-50,000 years cal BP. Radiocarbon 55(4):1869-87.

Scott EM, Cook GT, Naysmith P. 2010. A report on phase 2 of the Fifth International Radiocarbon Intercomparison (VIRI). Radiocarbon 52(2-3): 846-58.

Solís C, Chávez-Lomelí E, Ortiz ME, Huerta A, Andrade E, Barrios E. 2014. A new AMS facility in Mexico. Nuclear Instruments and Methods in Physics Research B 331:233-7.

Sosa-Nájera S, Lozano-Garcia S, Roy PD, Caballero M. 2010. Registro de sequías históricas en el occidente de México con base en el análisis elemental de sedimentos lacustres: el caso del lago de Santa María del Oro. Boletín de la Sociedad Geológica Mexicana 62(3):437-51.

Wacker L, Němec M, Bourquin J. 2010. A revolutionary graphitisation system: fully automated, compact and simple. Nuclear Instruments and Methods in Physics Research B 268(7-8): 931-4.

Yarza Carreón E. 2003. Los volcanes del sistema volcánico transversal. Investigaciones Geográficas 50:220-34. 